\title{
O.I. Бондаренко
}

\section{Дослідження кальцісвих каналів мітохондріальної мембрани ендотеліальних клітин}

\begin{abstract}
Надходження $\mathrm{Ca}^{2+}$ в мітохондріі, щ⿻о забезпечується так званим мітохондріальним кальцієвим уніпортером, відіграє иентральну роль у продукиії АТФ, регуляції внутрішньоклітинного кальцієвого гомеостазу та відкритті мітохондріальної пори. Враховуючи це, дослідження механізмів, шо забезпечують вхід $\mathrm{Ca}^{2+}$ в мітохондрії нині є надзвичайно актуальними, оскільки їх розуміння дає можливість впливати на функціональну активність і життєздатність клітин, безпосередньо модулюючи вміст мітохондріального кальцію. Донедавна дослідження процесів надходження $\mathrm{Ca}^{2+}$ в мітохондріі було значною мірою обмежено непрямими методами, здебільшого оптичними. Застосування методу фіксациї потенціалу до внутрішньої мембрани ізольованих мітохондрій дало змогу дослідити поодиноку активність кальијійровідних каналів. У роботі, проведеній на мітопластах (мітохондіях без наружноі мембрани), ізольованих від ендотеліальних клітин, у конфігурації mitoplast-attached методу patch-clamp описані електрофізіологічні властивості кальиійпровідних каналів внутрішньої мітохондріальної мембрани. Показано наявність трьох типів провідності кальцієвих каналів. Одержані результати свідчать про комплексну природу механізмів, щзо забезпечують надходження кальцію в мітохондрії і наявність альтернативних до мітохондріального кальцієвого уніпортера шляхів надходження.
\end{abstract}

Ключові слова: мітопласти, кальцієві канали, ендотеліальні клітини.

\section{ВСТУП}

Мітохондрії відіграють важливу роль у регуляції функцій і життєздатності клітин, забезпечуючи синтез АТФ, підтримання внутрішньоклітинного кальцієвого гомеостазу та вміст вільних радикалів. Крім того, завдяки регуляції відкриття мітохондріальної пори, $\mathrm{Ca}^{2+}$, що надходять у мітохондріальний матрикс, ці органели визначають індукцію загибелі клітин. Останніми дослідженнями доведено, що індукція мітохондіальної пори (МП) є однією з ланок патогенезу таких станів, як ішемічно-реперфузійні ушкодження серця та мозку, діабет, хвороба Паркінсона тощо [8].

Різноманітність функцій мітохондрій тісно пов'язана $з$ їх здатністю захоплювати, акумулювати та вивільнювати іони кальцію в цитозоль. Трансмітохондріальний транспорт кальцію, як відомо, відіграє активну роль у (C) O.I. Бондаренко регуляції внутрішньоклітинної кальцієвої сигналізації та надходженні кальцію через депокеровані кальцієві канали [16]. Хоча здатність мітохондрій акумулювати $\mathrm{Ca}^{2+}$ відома 3 початку 60-х років минулого століття, механізми їх транспорту в мітохондріальний матрикс на теперішній час не є визначеними та залишаються дуже актуальними.

Вважається, що $\mathrm{Ca}^{2+}$-акумулююча функція мітохондрій забезпечується так званим кальцієвим уніпортером, чутливим до рутенієвого червоного (RuR). Нещодавно було вперше показано, що мітохондріальний кальцієвий уніпортер є високоселективним кальцієвим каналом, який за відсутності двовалентних катіонів $є$ натрійпровідним [11]. При цьому амплітуда струму, викликаного переносом $\mathrm{Na}^{+}$, значно перевищує таку, що розвивається внаслідок надходження $\mathrm{Ca}^{2+}$ у матрикс. Дослідження останніх років, 
проведені із застосуванням флуоресцентних зондів, виявили залучення декількох протеїнів у трансмітохондріальний транспорт $\mathrm{Ca}^{2+}$, серед яких MICU1 [14], MCUR1 [13], роз'єднувальні білки (UCP2 I UCP3) [18], ріанодинові рецептори [17], ТRPC3-канали [9], і протеїн CCDC109A, який було перейменовано на мітохондріальний кальцієвий уніпортер (MCU) [2, 7]. Реєстрація струмів у конфігураціï cell-attached виявила декілька типів активності поодиноких кальцієвих каналів у внутрішній мітохондріальній мембрані кардіоміоцитів $[15,17]$. У мітохондріях, ізольованих з HeLa-клітин, було виявлено три типи активності цих каналів [3], що свідчить про комплексу природу механізмів транспорту $\mathrm{Ca}^{2+}$ в мітохондрії. Враховуючи важливу роль мітохондрій у регуляції функції і сигналізації ендотеліальних клітин $[5,6,12]$, мета роботи полягала в дослідженні біофізичних властивостей каналів, що забезпечують надходження кальцію в мітохондрії ендотеліальних клітин.

\section{МЕТОДИКА}

Ендотеліальні клітини лінії ЕА.hy926, що походять від ендотеліальних клітин пуповинних артерій людини [8], вирощували в культуральному середовищі Ігла модифікації, Дюльбекко (DMEM) 3 додаванням 10\%-ї телячої сироватки. Мітохондрії були ізольовані методом диференційного центрифугування [13]. Їх суспензували у розчині такого складу (ммоль/л): HEPES - 10, сахароза - 250, АТФ - 1, АДФ - 0,08, сукцинат - 5, $\mathrm{KH}_{2} \mathrm{PO}_{4}$ -2 , дитіотреїтол $-1, \mathrm{pH}$ доводили до 7,4 за допомогою КОН. Мітопласти отримували 3 ізольованих мітохондрій їхньою інкубацією протягом 7 хв у гіпотонічному розчині такого складу (ммоль/л): HEPES - 5, сахароза - 5, ЕГТА - 1, рН 7,2. Після цього ізотонічність відновлювали додаванням 0,2 об'єму гіпертонічного розчину (ммоль/л): $\mathrm{KCl}-750$, HEPES - 80, ЕГТА - 1; pH 7,4.

Поодинокі іонні канали реєстрували 3 використанням методу patch-clamp у pe- жимі фіксації потенціалу в конфігураціях mitoplast-attached та whole-mitoplast. Для реєстрації активності кальцієвих каналів у конфігурації mitoplast-attached піпетки заповнювали розчином, що містив 105 ммоль/л $\mathrm{CaCl}_{2}, 10$ ммоль/л HEPES. Опір піпеток становив 8-12 МОм. Для попередження відкриття МП і активності мітохондріального $\mathrm{Na}^{+}-\mathrm{Ca}^{2+}$-обмінника у розчин додавали $\mathrm{RuR}$ (10 мкмоль/л) та CGP37157 (20 мкмоль/л). Значення потенціалів наведені стосовно внутрішньої поверхні мембрани. Для реєстрації кальцієвих струмів у конфігурації wholemitoplast піпетки заповнювали розчином такого складу (ммоль/л): метансульфонат $\mathrm{Cs}-120, \mathrm{CsCl}-30$, ЕГТА-1, сахароза - 110, глюконова кислота - 2; pH 7,2. Базовий зовнішній розчин у цих експериментах містив (ммоль/л): тріс-НCl - 150, ЕГТА - 1, ЕДТА 1 , HEPES - 10. Після отримання конфігурації whole-mitoplast, мітопласти підтримували при потенціалі 0 мВ. Ремпові зсуви мембранного потенціалу від -160 до +50 мВ впродовж 1 с прикладали кожні 10 с. Натрієвий струм викликали еквімолярним заміщенням тріс ${ }^{+}$на $\mathrm{Na}^{+}$у зовнішньоклітинному розчині. Результати реєстрували за допомогою підсилювача НЕКА-7. Їх оцифровували 3 частотою 10 кГц, фільтрували низькочастотним фільтром Беселя та зберігали на жорсткому диску комп'ютера. Аналіз отриманих результатів проводили за допомогою програми Clampfit 9.2 ("Molecular Devices ", США).

\section{РЕЗУЛЬТАТИ}

3 літературних даних видно [11], що у середовищі, котре не містить двовалентних катіонів у відповідь на ремпові зсуви підтриманого потенціалу до значень мембранного потеніалу мітохондрій розвивається інтегральний струм, який переноситься $\mathrm{Na}^{+}$. Амплітуда вхідного натрієвого струму через мітохондріальну мембрану перевищує таку, що розвивається внаслідок $\mathrm{Ca}^{2+}$. Тому біофізичні властивості кальцієвих каналів у 
таких умовах досліджувалися переважно при використанні $\mathrm{Na}^{+}$як проникних іонів.

У конфігурації ціла клітина, еквімолярна заміна тріс- $\mathrm{HCl}$ у базовому зовнішньоклітинному розчині на $\mathrm{NaCl}$ під час ремпових зсувів призводила до розвитку вхідного струму при негативних потенціалах (рис. 1). За контрольних умов при потенціалі -160 мВ ампліуда натрієвого струму була $-652 \pm 27$ пА (n=5). Цей струм пригнічувався додаванням 10 мкмоль/л RuR, блокатора мітохондріального кальцієвого уніпортера. Наші результати демонструють наявність при негативних потенціалах чутливого до $\mathrm{RuR}$ вхідного натрієвого струму в мітопластах ендотеліальних клітин.

У конфігурації mitoplast-attached iз 105 ммоль/л $\mathrm{CaCl}_{2}$ у піпетці при потенціалах від -100 до -150 мВ спостерігалося 3 типи активності, які відрізнялися за провідністю. Першим типом активності був канал з провідністю 13 пСм (рис. 2,a), який спостерігався у 9 активних відведеннях 314 (вірогідність $64 \%$ ). Другим типом активності був канал 3 провідністю 7 пСм (див. рис. 2,б). Він спостерігався у 4 відведеннях 314 активних. Активність цього типу була в діапазонах від -80 до -160 мВ.
Крім описаних вище було зареєстровано ще один тип активності з провідністю 35 пСм і який мав пачкову активність (див. рис. 2,в). Цей тип активності спостерігався найменш часто і був зареєстрований у 3 відведеннях з 14 активних.

Таким чином, на внутрішній мітохондріальній мембрані ендотеліальних клітин за наявності зовнішньомітохондріального $\mathrm{Ca}^{2+}$ було ідентифіковано 3 типи активності поодиноких каналів. Всі вони спостерігались у діапазоні потенціалів від -80 до -160 мВ і були залежними від $\mathrm{Ca}^{2+}$ ззовні. Вхідні струми також викликалися після заміни зовнішньоклітинних іонів калію на тріс.

Для визначення селективності каналів у серіі експериментів піпетки замість розчину, що містив 105 ммоль/л $\mathrm{CaCl}_{2}$ та 10 ммоль/л HEPES, наповнювалися розчином, що містив 150 ммоль/л NMDGCl, 1 ммоль/л ЕГТА, 10 ммоль/л HEPES. У цих експериментальних умовах при потенціалах в діапазоні від -100 до -150 мВ вхідні струми не спостерігалися $(\mathrm{n}=7)$, вказуючи на те, що вхідні струми через досліджувані канали переносяться $\mathrm{Ca}^{2+}$. Ці експерименти свідчать про гетерогенність механізмів надходження іонів $\mathrm{Ca}^{2+}$ в мітохондрії.

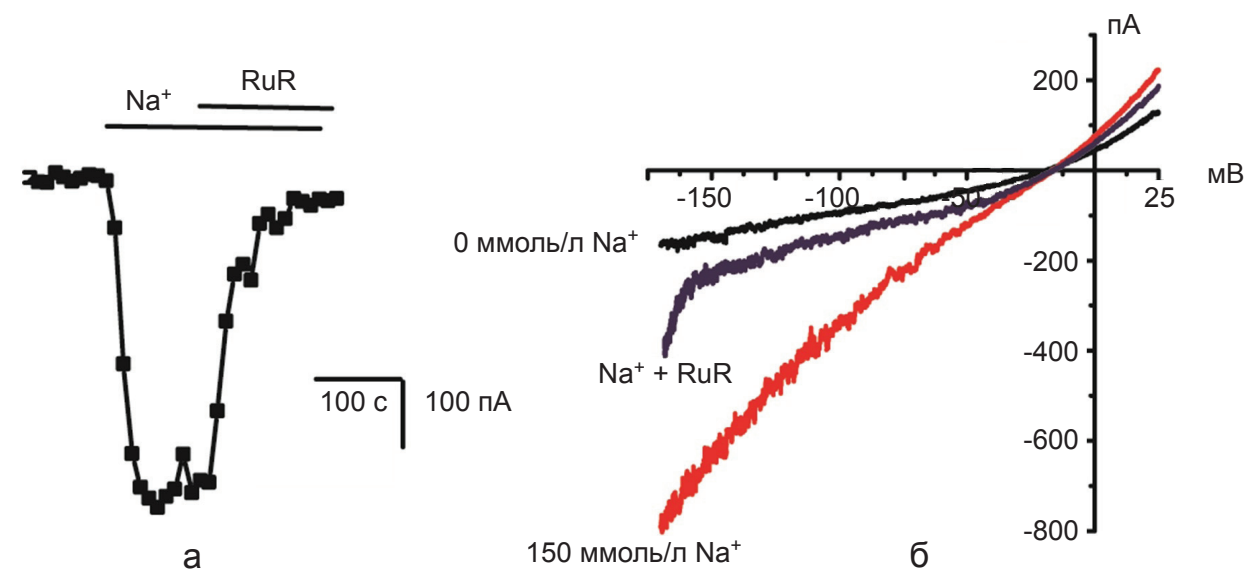

Рис.1. Вхідний натрієвий струм, чутливий до рутенієвого червоного (RuR; 10 мкмоль/л), через внутрішню мітохондріальну мембрану ендотеліальних клітин у конфігурації whole-mitoplast: a - часовий перебіг струму при потенціалі -160 мВ у відповідь на суперфузію зовнішньоклітинного розчину, що містив 150 ммоль/л $\mathrm{NaCl}, 1$ ммоль/л ЕГТА, 1 ммоль/л ЕДТА, 10 ммоль/л HEPES; б - трансмембранні інтегральні струми у безнатрієвому розчині за наявності 150 ммоль/л $\mathrm{Na}^{+}$до та після додавання RuR 


\section{ОБГОВОРЕННЯ}

Дослідження механізмів надходження кальцію в матрикс мітохондрій переважно проводяться із застосуванням непрямих методів, які унеможливлюють фіксацію багатьох параметрів реєстрації. Застосування методу patch-clamp відкриває можливість безпосередньо реєструвати кальцієві струми скрізь мітохондріальну мембрану за умов фіксації потенціалу і іонного складу матриксу, а також зовнішньомітохондріального оточення. Показано, що застосування конфігурації wholemitoplast дає змогу зареєструвати вхідний інтегральний струм через внутрішню мембрану мітохондрій, який $є$ чутливим до RuR. I3 застосуванням конфігурації mitoplast-attached нами диференційовано три типи поодинокої

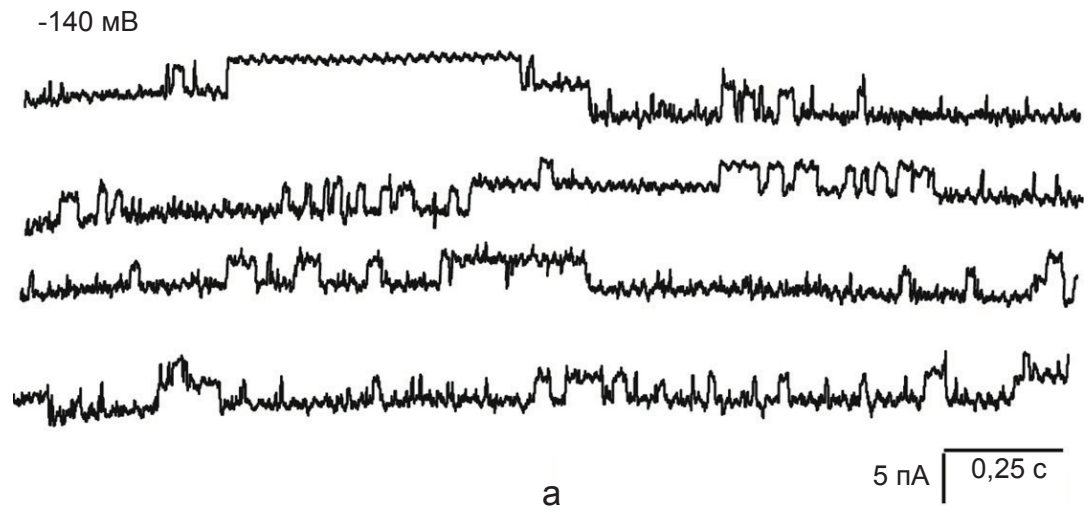

$-160 \mathrm{MB}$

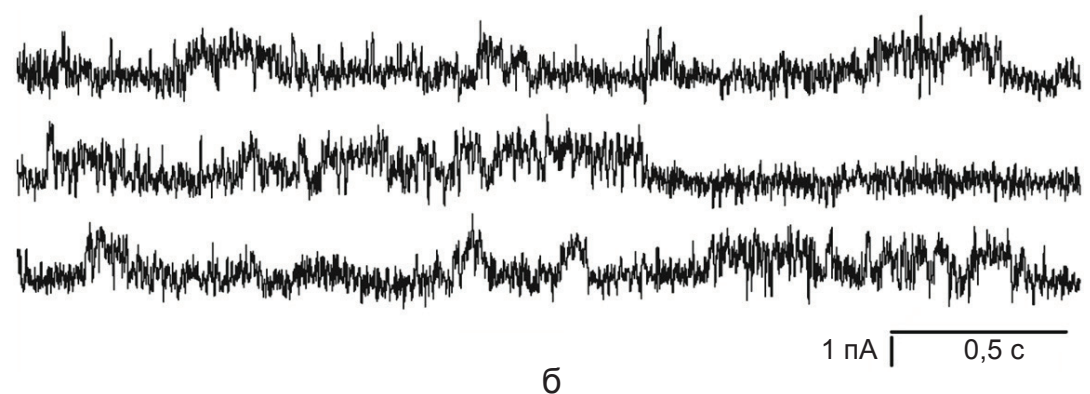

$-140 \mathrm{MB}$

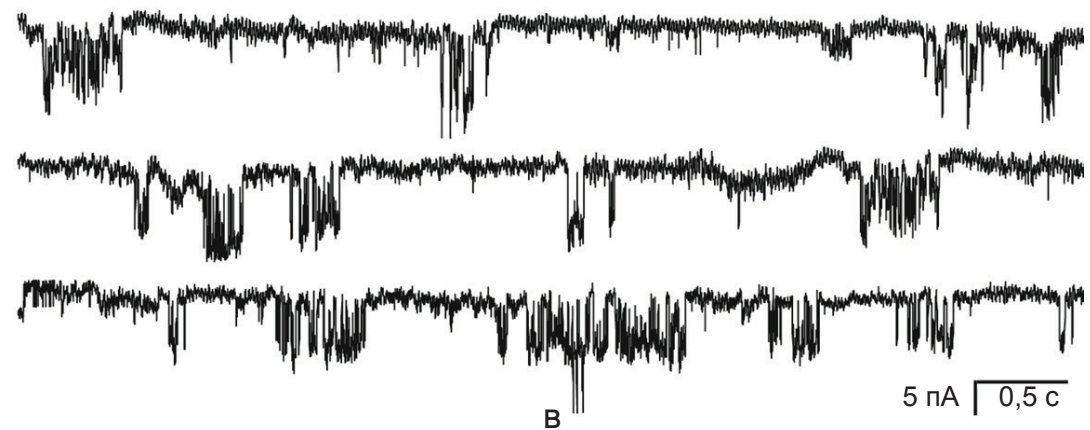

Рис. 2. Поодинока активність кальцієвих каналів внутрішньої мембрани мітохондрій ендотеліальних клітин з різною провідністю: а - 13 пСм при підтриманому потенціалу -140 мВ; б - 7 пСм при підтриманому потенціалу -160 мВ; в -35 пСм при підтриманому потенціалу -140 мB 
активності вхідних струмів при потенціалах, близьких до потенціалу мітохондрій. Оскільки при застосуванні безкальцієвого розчину у піпетці поодинока активність при досліджених потенціалах не спостерігалася, можна зробити висновок, що зареєстрована активність належить до кальційпровідних каналів. Три типи кальцієвої провідності у внутрішній мітохондріальній мембрані вказує на комплексну регуляцію надходження кальцію в мітохондрії та, ймовірно, про наявність декількох молекулярних структур, що виконують функцію транспорту кальцію в мітохондрії ендотеліальних клітин.

Отримані результати добре узгоджуються $з$ сучасними даними, які демонструють наявність декількох протеїнів у внутрішній мітохондріальній мембрані, що забезпечують і регулюють захоплення мітохондріями іонів кальцію $[7,9,13,14,17]$. Дослідження на мітопластах ізольованих від клітин HeLa, що походять 3 ракової пухлини шийки матки, раніше дали змогу нам також виявити три типи провідності кальційпровідних каналів [3]. Проте описані в нашій роботі два типи кальцієвої провідності в мітопластах ендотеліальних клітин (7 та 35 пСм) відрізняються від зареєстрованих раніше в мітопластах, ізольованих від HeLa-клітин (26 та 75 пСм), водночас третій тип спостерігався в мітопластах обох об'єктів [3]. У мітопластах, ізольованих з серцевої тканини людини [15], було ідентифіковано два типи провідностей кальцієвих каналів в умовах, ідентичних тим, в яких проведені наші експерименти. Цікаво, що значення провідностей, ідентифікованих в мітохондріях серцевого м'яза $(13,7$ та 7,7 пСм), були дуже близькими до таких, що описані в нашій роботі. Проте в мітохондріях ендотеліальних клітин нами ідентифіковано третій тип активності, що носив пачковий характер, з поодинокою провідністю 35 пСм, яка не була ідентифікована в мітопластах серцевого м'яза. Нещодавно було продемонстровано, що роз'єднувальні білки (UCP2 i UCP3) відіграють важливу роль у надхо- дженні кальцію в мітохондрії ендотеліальних клітин [18]. Проте їх значення у транспорті кальцію в мітохондрії підшлункової залози не було подтверджено [1]. Подальші дослідження потребують ідентифікації специфічних протеінів внутрішньої мітохондріальної мембрани, що забезпечують або контролюють регуляцію кальційпровідних каналів мітохондрій ендотеліальних клітин.

\section{А.И. Бондаренко \\ ИССЛЕДОВАНИЯ КАЛЬЦИЕВЫХКАНАЛОВ МИТОХОНДРИАЛЬНОЙ МЕМБРАНЫ}

Поступление $\mathrm{Ca}^{2+}$ в митохондрии, обеспечиваемое митохондриальным кальциевым унипортером, играет центральню роль в продукции АТФ, регуляции внутриклеточного кальциевого гомеостаза, а также в открытии митохондриальной поры. До недавного времени понимание процессов поступления $\mathrm{Ca}^{2+}$ в митохондрии было в значительной степени ограничено исследованиями с применением непрямых методов, главным образом оптических. Метод фиксации потенциала позволил исследовать на внутренней мембране изолированных митохондрий одиночную активность кальцийпроводящих каналов. В работе, проведеной на митопластах, изолированных от ендотелиальных клеток, описаны электрофизиологические свойства кальцийпроводящих каналов внутренней митохондриальной мембраны. Показано присутствие трех типов проводимости каналов. Полученные результаты свидетельствуют о комплексной природе механизмов, обезпечивающих поступление кальция в митохондрии и существование альтернативных к митохондриальному кальциевому унипортера путей поступления.

Ключевые слова: митохондрии, кальциевые каналы, эндотелиальные клетки.

\section{A.I. Bondarenko \\ SINGLE CHANNEL RECORDINGS REVEAL DISTINCTIVE CHARACTERISTICS OF $\mathrm{CA}^{2+}$-PERMEABLE CHANNELS IN THE MITOCHONDRIAL MEMBRANE}

Mitochondria play a central role in the regulation of cell function. $\mathrm{Ca}^{2+}$ entry into mitochondria represents a central event in the regulation of ATP production, intracellular $\mathrm{Ca}^{2+}$ homesotasis and mitochondrial permeability transition pore opening. Until recently, our understanding of the mechanisms of mitochondria $\mathrm{Ca}^{2+}$ uptake was largely limited by the use of indirect optical methods. Utilization of patch-clamp method to isolated mitoplasts allowed characterizing single channel properties of $\mathrm{Ca}^{2+}$ permeable channels in the inner mitochon- 
drial membrane. Here we show the presence of three types of single channel activities of $\mathrm{Ca}^{2+}$ permeable channels in mitoplasts isolated from endothelial cells. While the identity and molecular structure of these channels still remain to be identified, these findings point for complex mechanisms of $\mathrm{Ca}^{2+}$ entry in mitochondria.

Key words: mitochondria, calcium channels, patch-clamp.

Bogomoletz Institute of Physiology, Kyiv, Ukraine; Institute of Molecular Biology and Biochemistry, Medical University of Graz, Austria

\section{REFERENCES}

1. Alam MR, Groschner LN, Parichatikanond W, Kuo L, Bondarenko AI, Rost R, M. Waldeck-Weiermair, M, Malli $\mathrm{R}$, Graier WF. Mitochondrial $\mathrm{Ca}^{2+}$ uptake 1 (MICU1) and mitochondrial $\mathrm{Ca}^{2+}$ uniporter (MCU) contribute to metabolism-secretion coupling in clonal pancreatic betacells. J Biol Chem 2012; 287:34445-54.

2. Baughman JM, Perocchi F, Girgis HS, Plovanich M, BelcherTimme CA, Sancak Y, Bao XR, Strittmatter L, Goldberger O, Bogorad RL, Koteliansky V, Mootha VK (2011) Integrative genomics identifies MCU as an essential component of the mitochondrial calcium uniporter. Nature 476:341-345.

3. Bondarenko AI, Jean-Quartier C, Malli R, Graier WF (2013) Characterization of distinct single-channel properties of $\mathrm{Ca}^{2+}$ inward currents in mitochondria. Pflugers Arch 465:997-1010.

4. Bondarenko AI, Jean-Quartier C, Parichatikanond W, Alam MR, Waldeck-Weiermair M, Malli R, Graier WF (2013) Mitochondrial $\mathrm{Ca}^{2+}$ uniporter (MCU)-dependent and $\mathrm{MCU}$-independent $\mathrm{Ca}^{2+}$ channels coexist in the inner mitochondrial membrane. Pflugers Arch.in press.

5. Bondarenko OI, Sahach VF (2006) [Role of mitochondria in reglulation of endothelial cell hyperpolarization to acetylcholine]. Fiziol Zh 52:6-11.

6. Bondarenko OI, Sahach VF (2011) [Mitochondrial Na+$\mathrm{Ca}^{2+}$-exchanger inhibitor CGP37157 produces endothelial cell depolarization with membrane potential oscillations]. Fiziol Zh 57:9-16.

7. De Stefani D, Raffaello A, Teardo E, Szabo I, Rizzuto R (2011) A forty-kilodalton protein of the inner membrane is the mitochondrial calcium uniporter. Nature 476:336-340.

8. Duchen MR, Szabadkai G (2010) Roles of mitochondria in human disease. Essays Biochem 47:115-137.

9. Feng S, Li H, Tai Y, Huang J, Su Y, Zhu MS, Abramowitz J, Wang Y. Canonical transient receptor potential 3 channels regulate mitochondrial calcium uptake. Proc Natl Acad Sci U S A 2013; 110:11011-6.

10. Jean-Quartier C, Bondarenko AI, Alam MR, Trenker M, Waldeck-Weiermair, M, Malli R, Graier WF. Studying mitochondrial $\mathrm{Ca}^{2+}$ uptake - a revisit. Mol Cell Endocrinol 2012; 353:114-27.

11. Kirichok Y, Krapivinsky G, Clapham DE (2004) The mitochondrial calcium uniporter is a highly selective ion channel. Nature 427:360-364.

12. Malli R, Frieden M, Osibow K, Graier WF (2003) Mitochondria efficiently buffer subplasmalemmal $\mathrm{Ca}^{2+}$ elevation during agonist stimulation. J Biol Chem 278:10807-10815.

13. Mallilankaraman K, Cardenas C, Doonan PJ, Chandramoorthy HC, Irrinki KM, Golenar T, Csordas G, Madireddi P, Yang J, Muller M, Miller R, Kolesar JE, Molgo J, Kaufman B, Hajnoczky G, Foskett JK, Madesh M (2012) MCUR1 is an essential component of mitochondrial $\mathrm{Ca}^{2+}$ uptake that regulates cellular metabolism. Nat Cell Biol 14:1336-1343.

14. Mallilankaraman K, Doonan P, Cardenas C, Chandramoorthy HC, Muller M, Miller R, Hoffman NE, Gandhirajan RK, Molgo J, Birnbaum MJ, Rothberg BS, Mak DO, Foskett JK, Madesh M (2012) MICU1 Is an Essential Gatekeeper for MCU-Mediated Mitochondrial $\mathrm{Ca}^{2+}$ Uptake that Regulates Cell Survival. Cell 151:630644.

15. Michels G, Khan IF, Endres-Becker J, Rottlaender D, Herzig S, Ruhparwar A, Wahlers T, Hoppe UC (2009) Regulation of the human cardiac mitochondrial $\mathrm{Ca}^{2+}$ uptake by 2 different voltage-gated $\mathrm{Ca}^{2+}$ channels. Circulation 119:2435-2443.

16. Parekh AB (2008) Mitochondrial regulation of storeoperated CRAC channels. Cell Calcium 44:6-13.

17. Ryu SY, Beutner G, Kinnally KW, Dirksen RT, Sheu SS (2011) Single channel characterization of the mitochondrial ryanodine receptor in heart mitoplasts. J Biol Chem 286:21324-21329.

18. Trenker M, Malli R, Fertschai I, Levak-Frank S, Graier WF. Uncoupling proteins 2 and 3 are fundamental for mitochondrial $\mathrm{Ca}^{2+}$ uniport. Nat Cell Biol 2007; 9:445-52 